\title{
Chilling Injury in Peaches: A Cytochemical and Ultrastructural Cell Wall Study
}

\author{
J.G. Luza ${ }^{1}$, R. van Gorsel ${ }^{2}$, V.S. Polito, and A.A. Kader ${ }^{3}$ \\ Department of Pomology, University of California, Davis, CA 95616-8683 \\ Additional index words. Prunus persica, internal breakdown, physiological disorder, staining methods
}

\begin{abstract}
Fruits of mid- ('O'Henry'), late ('Airtime'), and extra-late-season ('Autumn Gem') peach [Prunus persica (L.) Batsch] cultivars were examined for changes in cell wall structure and cytochemistry that accompany the onset of mealiness and leatheriness of the mesocarp due to chilling injury. The peaches were stored at $10 \mathrm{C}$ for up to 18 days or at SC for up to 29 days. Plastic-embedded sections were stained by the Schiff's-periodic acid reaction, Calcofluor white MR2, and Coriphosphine to demonstrate total insoluble carbohydrates, B-1,4 glucans, and pectins, respectively. Mealiness was characterized by separation of mesocarp parenchyma cells leading to increased intercellular spaces and accumulation of pectic substances in the intercellular matrix. Little structural change was apparent in the cellulosic component of the cell walls of these fruits. In leathery peaches, the mesocarp parenchyma cells collapsed, intercellular space continued to increase, and pectin-positive staining in the intercellular matrix increased greatly. In addition, the component of the cell walls that stained positively for $\beta-1,4$ glucans became thickened relative to freshly harvested or mealy fruit. At the ultrastructural level, dissolution of the middle lamella, cell separation, irregular thickening of the primary wall, and plasmolysis of the mesocarp parenchyma cells were seen as internal breakdown progressed.
\end{abstract}

The postharvest life of peaches is often limited by chilling injury $(\mathrm{CI})$, which becomes evident in susceptible cultivars after 2 to 3 weeks of storage at temperatures below 10C (Lill et al., 1989). Lack of juiciness (mealiness, woolliness, or leatheriness), browning of the flesh, increased susceptibility to decay, and loss of ability to ripen are some of the CI symptoms of peach. Initial response to temperature is considered to involve physical factors such as membrane alterations and protein/enzyme diffusion; however, physiological changes that lead to losses of structural integrity and overall fruit quality also occur (Morris, 1982).

Peach cultivars perform differently in storage, with a tendency for late-season cultivars grown in California to have shorter storage life than early season cultivars (Mitchell and Kader, 1989). In a study conducted in Arkansas, 'Redhaven' and 'Redglobe' were least affected by CI, while 'Ranger' and 'Dixired' were most severely affected, although no seasonal effect was noted (Furmanski and Buescher, 1976).

A characteristic of ripening common to most fruits is an increase in the activity of cell wall-degrading enzymes that are responsible for fruit softening. Dissolution of the ordered arrangement of cell wall and middle lamella polysaccharides occurs (Dick and Labavitch, 1989). As a fruit ripens, a substantial portion of its cell wall pectins are converted to a water-soluble form and these changes are of considerable importance in fruit texture (Ben-Arie et al., 1979; Labavitch, 1981). Undesirable textural changes of the flesh due to CI have been associated with alteration of cell wall metabolism in peaches (Ben-Arie and Lavee, 1971; Ben-Arie and Sonego, 1980; Buescher and Furmanski, 1978).

In this paper we report on cytochemical and structural changes

Received for publication 19 Feb. 1991. Accepted for publication 4 Sept. 1991. Research supported, in part, by a grant from the California Tree Fruit Agreement. The cost of publishing this paper was defrayed in part by the payment of page charges. Under postal regulations, this paper therefore must be hereby marked advertisement solely to indicate this fact.

On leave from Facultad de Ciencias Agrarias y Forestalls, Universidad de Chile, Santiago, Chile.

Current address: Research Station for Floriculture, Linnaeuslaan 2A, 1431JV Aalsmeer, The Netherlands.

${ }^{3}$ To whom reprint requests should be addressed. that occur in walls of peach mesocarp cells during the development of CI (internal breakdown).

\section{Materials and Methods}

Cultivars and temperatures. Fruits of 'O'Henry' (midseason), 'Fairtime' (late-season), and 'Autumn Gem' (extra-late-season) peaches were harvested at similar stages of maturity (skin color and flesh firmness) on 9 and 31 Aug. and 29 Sept. 1989, respectively. Fruits were stored either at $10 \mathrm{C}$ for up to 18 days, or at $5 \mathrm{C}$ for up to 29 days. Two sets of samples were taken from both treatments: one to be analyzed immediately and a second to be analyzed after 6 days of ripening at 20C.

Fruit sampling. Rectangular samples of the mesocarp were taken parallel to the long axis of the fruit, $1 \mathrm{~cm}$ away from the stone (endocarp) at the point of greatest cross-sectional diameter. Tissue samples for light microscopy were $\approx 3 \times 3 \mathrm{~m}$ in the transverse plane and $5 \mathrm{~mm}$ in the longitudinal plane; those for electron microscopy measured $\approx 1 \times 1 \times 2 \mathrm{~mm}$. At each sampling, six mesocarp samples were taken from six fruits in each treatment; however, only three samples were actually sectioned. Sets of slides were made from each sample for use with each staining reaction.

Light microscopy. Several fixation procedures were evaluated. The best preservation was obtained after fixation in a solution containing $4 \%$ glutaraldehyde, $0.2 \mathrm{M}$ dipotassium phosphate, $0.1 \mathrm{M}$ citric acid monohydrate, and $4 \%$ sucrose at $\mathrm{pH}$ 7.0. To facilitate infiltration, samples were sectioned directly into the fixative and subjected to a mild vacuum for 30 rein, then were refrigerated overnight until further preparation. Fixed samples were washed in the selected buffer at room temperature, dehydrated through an ethanol series, and infiltrated with glycol methacrylate resin (DuPont-Sorvall, Wilmington, Del.) (modified from O'Brien and McCully, 1981). After trimming and reorientation of the embedded specimens, tangential sections were cut at $3 \mu \mathrm{m}$ using glass knives on a Sorvall JB4 microtome. Slides were stained as described below. Fluorescence observations were carried out on a Zeiss microscope equipped for epi-illumination with a HBO 50 mercury lamp.

Abbreviations: CI, chilling injury; PAS, periodic acid Schiff's reagent. 
Coriphosphine (Biomedical Specialties, Santa Monica, Calif.) was used for location of pectins (Ueda and Yoshioka, 1976; Weis et al., 1988). The stained slides were air-dried and mounted with Fluoromount (BDH Chemicals, Pool, U.K.). To visualize Coriphosphine-induced fluorescence, the excitation filter and reflector from a Zeiss 48-77-15 filter set was used to provide $546(* 12) \mathrm{nm}$ excitation; a $630( \pm 10)$-nm bandpass barrier filter was used to isolate pectin-specific emission wavelengths.

Calcofluor white MR2 (Polyscioacos, Warrington, Pa.) was used to stain $\beta-1,4$ glucans, including cellulose. Sections were stained for 2 rein, rinsed, air-dried, and mounted in Fluoromount. This stain emits a strong, pale-blue fluorescence in the presence of $\beta-1,4$ glucans (Hughes and McCully, 1975). Excitation was below $400 \mathrm{~nm}$ using a Zeiss 48-77-02 filter set.

Periodic acid Schiff's reagent (PAS) was used to stain insoluble carbohydrates (Jensen, 1962). For specificity, 2,4 dinitrophenyl hydrazine (DNPH) was used to block tissue aldehydes before the sections were stained (Pearse, 1972 Van Duijn, 1961). Samples were mounted in Permount (Fisher).

Transmission electron microscopy. The tissue was fixed in $4 \%$ glutaraldehyde in a phosphate-citrate buffer ( $\mathrm{pH} 7.0$ ) containing $4 \%$ sucrose for $1 \mathrm{~h}$, washed three times in the buffer, post-fixed in $2 \%$ osmium tetroxide in buffer for $1 \mathrm{~h}$, washed three times in buffer, and dehydrated through an ethanol series to absolute ethanol. The samples were infiltrated in Spurr's plastic and polymerized at $70 \mathrm{C}$ for $8 \mathrm{~h}$ under vacuum (adapted from Dawes, 1979). Sections were cut with a diamond knife using a Sorvall MT-2 ultramicrotome. Following gold deposition, sections were mounted on 300-mesh copper slim-bar grids. The sections were stained in a saturated solution of uranyl acetate in $50 \%$ ethanol for $30 \mathrm{sec}$ by placing the grids upside down on freshly filtered stain; excess stain was blotted off on filter paper. Sections were rinsed twice in double-distilled water. Grids were then stained in a $2 \%$ solution of lead citrate with sodium hydroxide for $30 \mathrm{sec}$ and washed twice in alternate solutions of $0.02 \mathrm{~N}$ sodium hydroxide and double-distilled water. Photographs and observations were made on a JEOL 100S transmission electron microscope (TEM) at $80 \mathrm{kV}$.

\section{Results}

Fixative solution. Mature and, especially, ripe fruit tissues are susceptible to plasmolysis and bursting due to the cell size and delicate nature of the tissue itself, of which the main component is the large central vacuole. Although the osmolality of the tissue and fixative was not determined under the conditions of fixation used here, the cellular contents, cell membranes, and cell walls remained largely intact and well organized.

Cultivars and temperatures. Striking cultivar differences in plasmalemma, cytoplasm, and cell changes were observed in response to temperature and duration of storage. The midseason cultivar O'Henry retained good quality for much longer (for 29 days) than the other two. The extra-late cultivar Autumn Gem was the first to develop the textural changes (softening) that result from the breakdown of cell wall constituents.

Overall, 10C was a much better temperature for short-term storage than 5C. 'O'Henry' and 'Fairtime' peaches did not develop any apparent CI symptoms for 18 and 14 days, respectively, at 5C, but 'Autumn Gem' peaches could not be kept longer than 12 days without symptoms of the early stages of CI (separation of mesocarp parenchyma cells) becoming evident with the light microscope. Although the three cultivars could all be stored for longer durations at $5 \mathrm{C}$ than at $10 \mathrm{C}$ without the development of noticeable CI symptoms during storage, symp- toms of CI developed rapidly upon transfer of peaches previously kept at 5 to $20 \mathrm{C}$ for ripening.

Stain reactions. The various stains used in this study revealed many of the cellular events that occur during ripening of peach mesocarp, each giving different, but complementary information. In samples stained with Calcofluor, cellulose walls fluoresced intensely and cytoplasmic components were completely unstained; Calcofluor was useful for showing differences in cell wall thickness and especially cell-cell separation. Coriphosphine stained pectins and showed organizational changes in the middle lamella. The amount of pectins in the intercellular spaces increased dramatically in fruit stored at 5C for 29 days ('O'Henry'), or longer than 19 ('Airtime') and 17 days ('Autumn Gem').

PAS staining is specific for insoluble polysaccharides. In combination with hematoxylin it provided a high-contrast stain for revealing general structure that was useful for showing cell plasmolysis, the cytoplasm, vacuole, and especially cell wall thickness. It revealed that vascular tissue, especially phloem, has much more PAS-positive substances than do the mesocarp cells.

Mature and early senescent stages. Anatomical analysis of fully mature fruit (based on flesh firmness) indicated that there are no marked differences among the mesocarps of the three cultivars studied. Mesocarp tissue and cell anatomy from freshly harvested peaches were similar and, while cell size varied considerably in the same tissue, all displayed closely appressed, turgid parenchymatous cells, with thin primary walls and distinct intercellular spaces (Fig. $1 \mathrm{~A}$ and B). The cell walls were sharply delineated following PAS staining and the intercellular spaces were PAS negative (Fig. IC). Walls showed a strong positive reaction to Calcofluor, evident as bright fluorescence with a clear, largely unstained, middle lamella region (Fig. 1 D and E). Coriphosphine staining also revealed thin, uniformly staining primary walls and no staining was evident in the intercellular spaces (Fig. 1F).

No breakdown was apparent at the electron microscope level in any freshly harvested fruit. The cells contained intact plasmalemma tightly appressed to the walls, a thin layer of peripheral cytoplasm, and an intact tonoplast. Cell walls were uniform in thickness and comprised of densely packed fibrils in an electron-translucent matrix (Fig. 1G). The middle lamella was visible as a relatively electron-dense region between the primary walls. The cells were largely vacuolated with cytoplasm confined to a narrow layer adjacent to the cell wall (Fig. $1 \mathrm{H}$ ).

Early symptoms of CI were evident in some 'Autumn Gem' mesocarp cells. The plasma membrane, although still adjacent to the cell wall, developed an irregular contour, and the cytoplasm together with the plasma membrane became drawn away from the wall (Fig. 11). Changes in the structure of the cell wall appeared at this stage. Dissolution of the middle lamella became apparent in some cells as electron-translucent regions and an increasing fibrillar appearance in the wall (Fig. $1 \mathrm{~J}$ and $\mathrm{K}$ ). In fruits that had softened but did not yet show symptoms of mealiness, cell wall separation was widespread, beginning at the intercellular spaces and moving along the adjacent cell walls (Fig. $1 \mathrm{~K}$ and $\mathrm{L}$ ).

The cell ultrastructure of 'Autumn Gem' peaches kept for 12 days at $5 \mathrm{C}$ resembled that of freshly harvested fruit. The plasma membrane and vacuolar membrane had retained their relative positions within the cell wall. However, in some cells, an early stage in the breakdown was shown by cells that exhibited a narrow electron-translucent zone outside the plasmalemma.

Mealiness. Mealiness began to appear in 'O'Henry', 'Fair- 


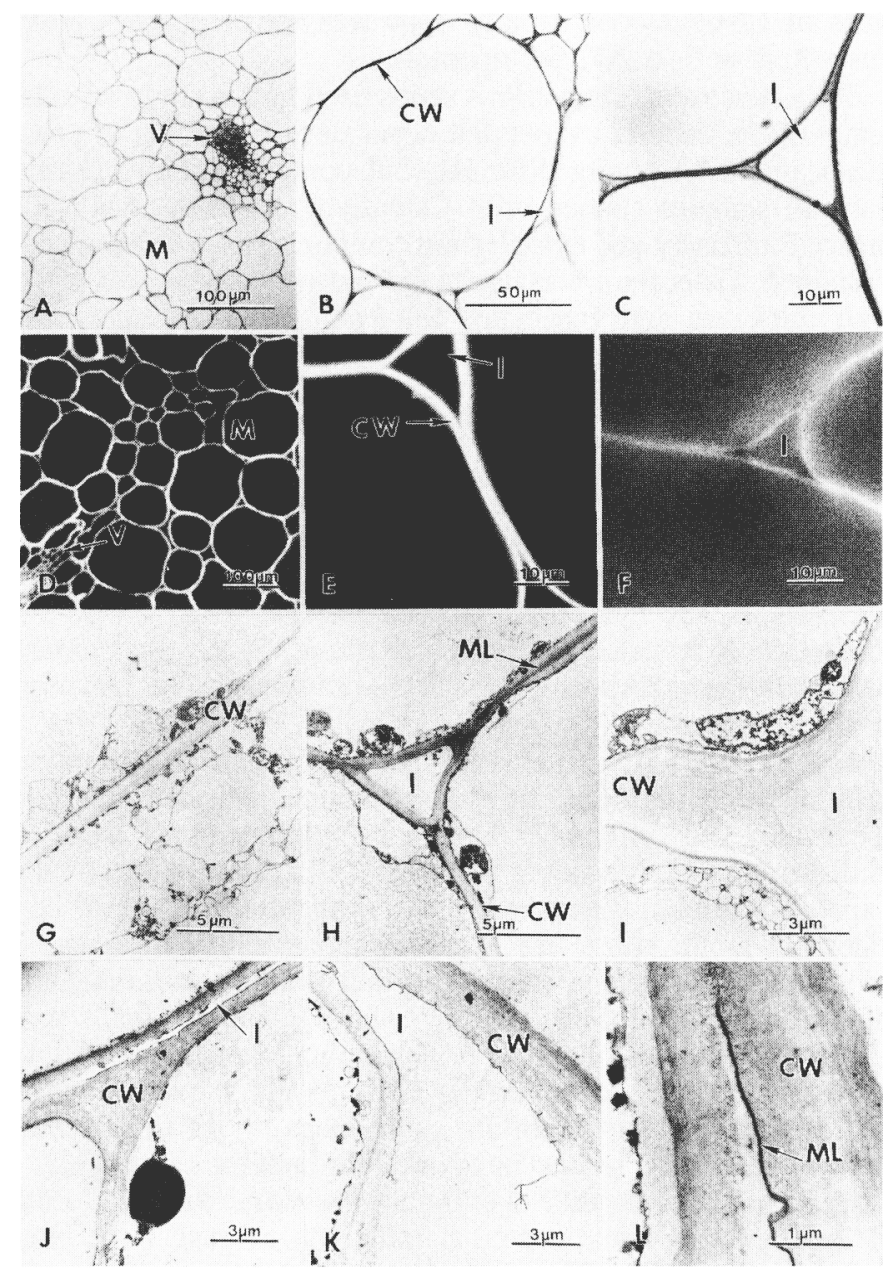

Fig. 1. Mature and early senescent tissue from peach mesocarp. (AF) Light micrographs of freshly harvested 'O'Henry' peach fruits. (A) PAS-stained; (B) PAS-stained; (C) PAS-stained; (D) Calcofluor white-stained; (E) Calcofluor white-stained; (F) biphosphine-stained; ( $\mathbf{G}$ and $\mathbf{H}$ ) transmission electron micrographs of mesocarp of freshly harvested 'Autumn Gem' peaches; (I-L) early changes in ultrastructure after 6 days at $20 \mathrm{C}$ following 14 days at $5 \mathrm{C}$ of 'Autumn Gem' peaches. $\mathrm{CW}=$ cell wall; $\mathrm{I}=$ intercellular space; $\mathrm{M}=$ mesocarp; $\mathrm{ML}=$ middle lamella; $\mathrm{V}=$ vascular tissue .

time', and 'Autumn Gem' peaches after 29, 19, and 17 days, respectively. Mesocarp cells became contorted (Fig. 2A) and the expansion of intercellular spaces caused separation of adjacent cell walls (Fig. 2 A and B). The newly formed intercellular spaces showed a diffuse positive staining with PAS (Fig. $2 \mathrm{~B}$ and C). Calcofluor staining showed separated cells with sharply delineated, thin cell walls similar in thickness to those in nonsymptomatic fruits. Intercellular spaces were not stained by Calcofluor (Fig. $2 \mathrm{D}$ and E). By contrast, Coriphosphine staining at this stage resulted in intense fluorescence in the intercellular spaces. The pattern of Coriphosphine fluorescence in the intercellular space appeared to follow the pattern of cell separation, being particularly intense in the regions of the original intercellular spaces and less so in areas where cells that had been adjacent became separate (Fig. 2F). The regions of the cell wall that were positive for Calcofluor were unstained or only lightly stained by Coriphosphine (Fig. 2 E and G).

At the ultrastructural level, the middle lamella region became

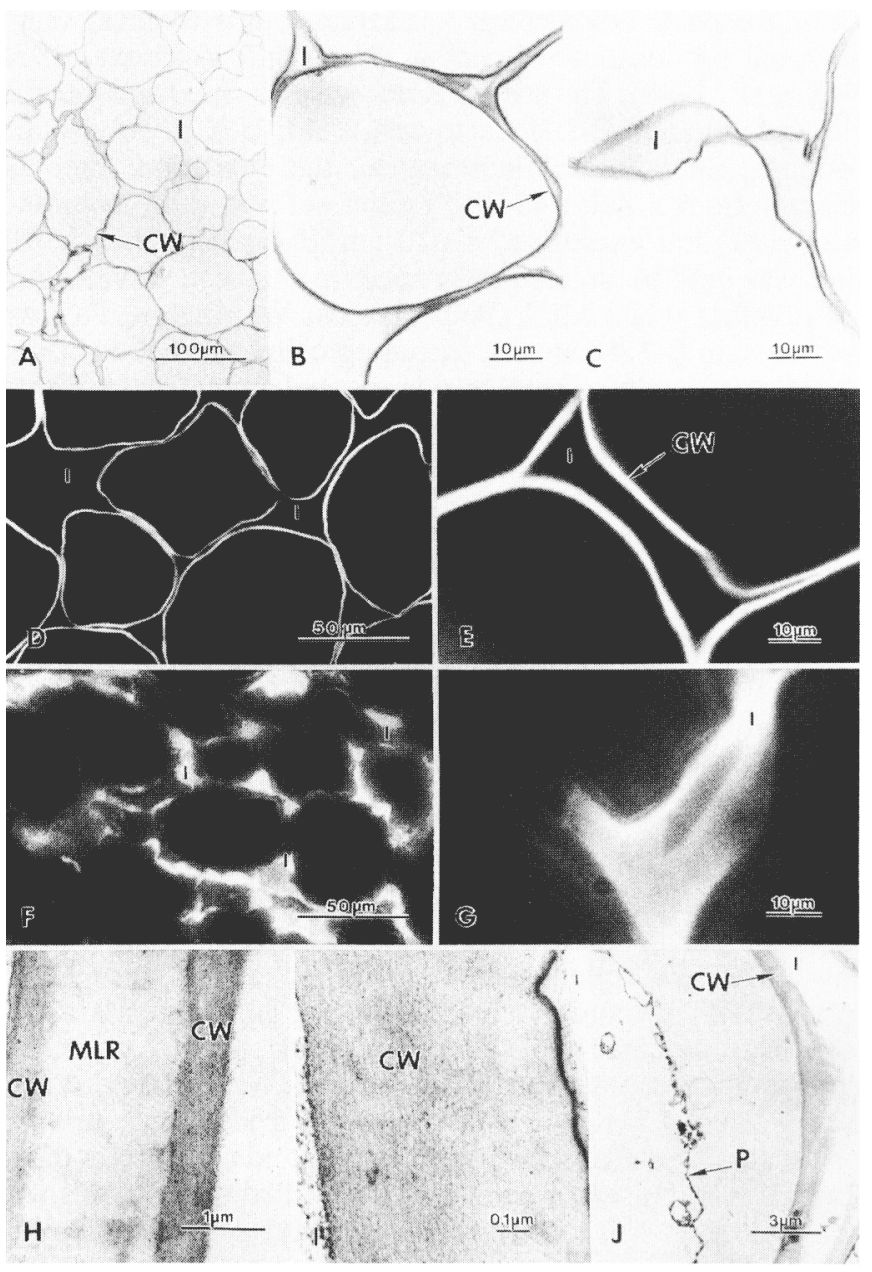

Fig. 2. CI manifested as mealiness in peach mesocarp. (A-G) Light micrographs of 'Fairtime' peaches kept for 6 days at 20C following 19 days at 5C. (A) PAS-stained; (B and C) PAS-stained; (D) Calcofluor-stained; (E) Calcofluor-stained; (F) Coriphosphine-stained; (G) Coriphosphine-stained; (H-J) transmission electron micrographs of the cell wall of 'Autumn Gem' peaches stored 6 days at $20 \mathrm{C}$ after 17 days at $5 \mathrm{C}$. $\mathrm{CW}=$ cell wall; $\mathrm{I}=$ intercellular space; $\mathrm{MLR}=$ middle lamella region; $\mathrm{P}=$ plasmalemma.

electron-translucent and bordered by the more electron-dense, fibrillar primary cell walls. Some diffuse electron density was evident at the sites of the original intercellular spaces (Fig. $2 \mathrm{H}$ and I). The plasma membrane had receded from the cell wall (Fig. 2J).

Leatheriness. Leatheriness appeared only in 'Autumn Gem' peaches kept for 6 days at 20C following storage at 5C for 22 days or longer. These fruits had markedly deformed internal mesocarp cells that had collapsed completely, leaving sharp protrusions of the cell walls (Fig. 3A), which had become thickened (Fig. 3B). Large regions of the mesocarp showed diffuse PAS staining in the intercellular matrix (Fig. 3C). This staining was more widespread and denser than that in mealy fruit. Thickened walls were evident in the Calcofluor-stained sections (Fig. $3 \mathrm{D}$ and $\mathrm{E}$ ); these showed a more diffuse wall structure than the sharply delineated structure exhibited following Calcofluor staining in samples taken earlier. The intercellular spaces were brightly fluorescent after Coriphosphine staining, with Coriphosphinepositive materials essentially filling the intercellular matrix (Fig. $3 \mathrm{~F}$ and $\mathrm{G})$. 


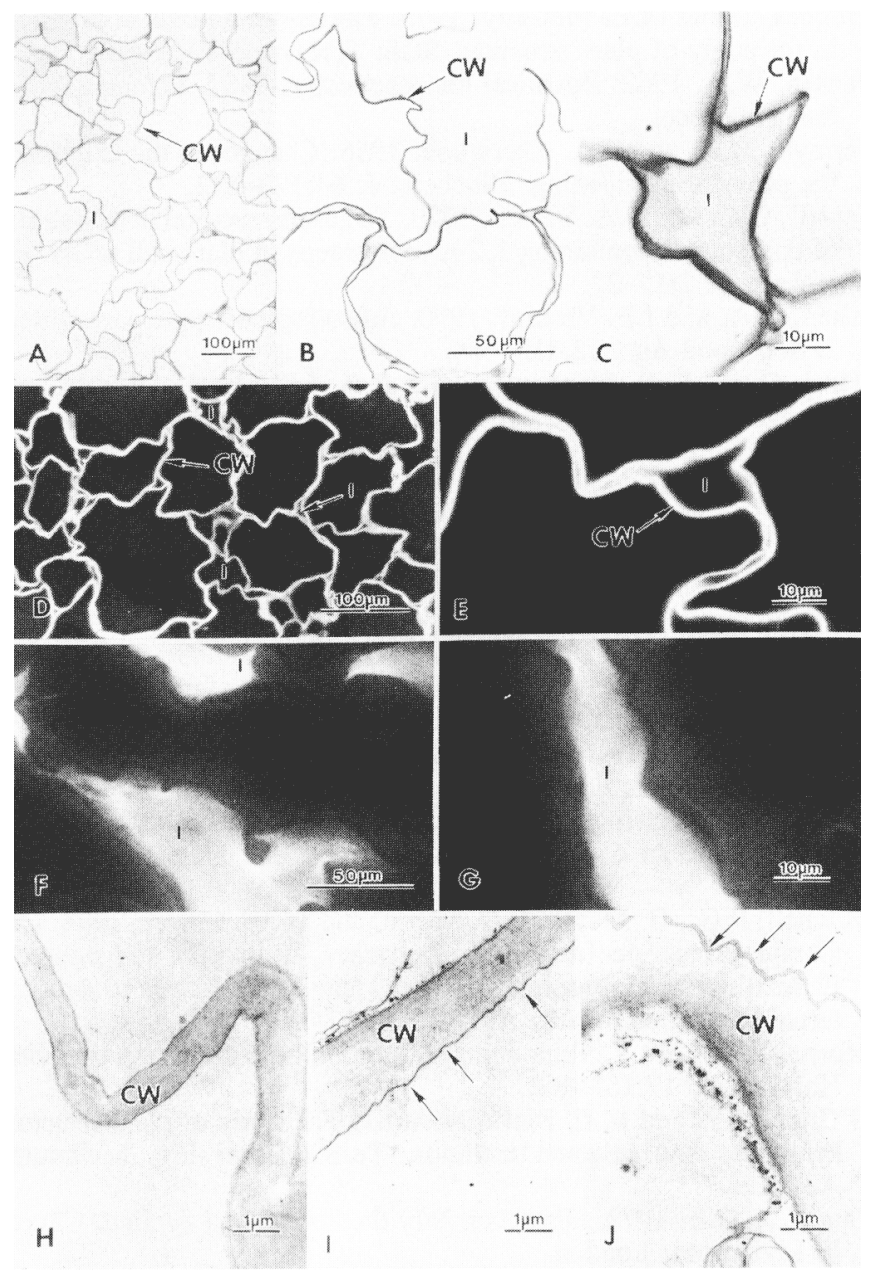

Fig. 3. CI-induced leatheriness in 'Autumn Gem' peaches kept for 6 days at 20C following 22 days at SC. (A) PAS-stained; (B) PASstained; (C) PAS-stained; (D) Calcofluor-stained; (E) Calcofluorstained; (F) Coriphosphine-stained; (G) Coriphosphine-stained; (HJ) transmission electron micrographs showing deformation and thickening of the cell wall. Arrows indicate regions of irregular thickenings of the cell wall. $\mathrm{CW}=$ cell wall; $\mathrm{I}=$ intercellular space.

Cell wall thickening appeared irregular and the cell walls were bent, showing a collapsed cell shape (Fig. $3 \mathrm{H})$. Cell walls had become irregularly thickened (Fig. 3 I and J), sometimes becoming two or more times the thickness of that found in freshly harvested fruits. These preparations also revealed clear features of structural breakdown, including complete separation of the plasma membrane from the cell wall, disintegration of some vacuolar membrane, and in most cells complete disorganization of the cytoplasm.

\section{Discussion}

Peach pericarp tissue is known to be anisotropic (i.e., cell morphology-varies according to the direction from which it is viewed), so sampling procedures were a critical factor. Recent fruit morphological studies have also shown that anisotropy changes with stage of maturity in apples (Khan and Vincent, 1990) and apricots (Archibald and Melton,. 1987) due to different arrangement of cells in these fruits. The parenchyma anisotropy was eliminated as a factor because we used the same mesocarp region and plane of section throughout.
Our results indicate that staining for pectins, polysaccharides, and cellulose increased differentially during ripening (as indicated by softening), especially where CI symptoms were evident. In PAS, a stain for insoluble polysaccharides, periodic acid oxidizes 1,2-glycol groups to form aldehyde groups that, combined with Schiff's reagent, produces a colored product. Hemicelluloses are also PAS positive, while uronic acids and polyuronides are PAS negative (Jensen, 1962). Jewell and Saxton (1970) stated that it is the presence of arabinose and galactose in association with uronic substances in the middle lamella that give a PAS-positive reaction.

A sharp increase in Coriphosphine-induced fluorescence occurred in the intercellular matrix during the appearance of CI symptoms, indicating that cell wall pectin content is either low or nonexistent. This evidence supports pectin presence only between primary cell walls after middle lamella dissolution. However, Calcofluor staining patterns suggest the presence. of cellulose only in the primary cell walls, with an increase in leathery tissue.

Lack of juiciness is an important symptom of $\mathrm{CI}$ in peaches and is manifested either as mealiness or leatheriness, depending on cultivar and storage conditions. Genotypic differences in storage potential were evident in the cultivars examined here. This is consistent with the findings of Furmanski and Buescher (1976), King et al. (1989), and Mitchell et al. (1974), who reported that early and midseason peach cultivars have a longer storage life than late- and extra-late-season cultivars.

Fruit firmness is determined by a combination of internal water pressure and integrity of the cell wall. Structural changes in peach cell walls became apparent during early softening stages due to dissolution of the middle lamella and disintegration of cell wall fibrillar material. This is a well-known alteration during ripening of apple and pear fruits (Ben-Arie et al., 1979). In ripened, soft freestone peaches, the amount of pectin esterification dropped to a lower level than in clingstone peaches. This high retention of insoluble pectins in ripe clingstone peaches accounts for their much firmer flesh (Reeve, 1970).

The simplest relationship between texture and cell wall substances is represented by the development of mealiness during ripening (Reeve, 1970). King et al. (1989), working with 'Fantasia' nectarine, suggested that mealiness (pastiness) was associated with separation of the middle lamella without extensive degradation of the cell wall. We found this symptom after storage at $5 \mathrm{C}$. Affected cells showed that the larger primary walls separated, forming a continuous extracellular matrix. The intercellular spaces were characterized by the presence of amorphous pectic substances and polysaccharides. Jermyn and Isherwood (1956) indicated that in pear cell walls, polysaccharides are both degraded and synthesized during ripening. The amount of this amorphous jelly-like substance was more intense and evident in leathery peach tissue than at earlier stages.

Mealiness has been attributed to the presence of insoluble low methoxyl-pectic substances of high molecular weight that are formed by the action of pectinesterase during chilling (BenArie and Lavee, 1971; Ben-Arie and Sonego, 1980; Buescher and Furmanski, 1978; Lill et al., 1989). Our observations support this hypothesis. Shewfelt (1965) reported that the amount, changes of total pectin content, and ripening depended on peach cultivar. Our data indicate intercultivar differences in the amount of pectin materials that bound free water and cell fluids in the intercellular spaces resulting in mealiness (lack of juiciness).

The high degree of cell wall thickening in leathery fruits implies that some cell wall synthesis may have occurred in this 
altered tissue. Recent work involving incorporation of ${ }^{14} \mathrm{C}$-labeled sucrose (Mitcham et al., 1989) and ${ }^{13} \mathrm{C} 6$-labeled glucose (Greve and Labavitch, 1989) into tomato pericarp cell wall indicates that the fruit's ability to synthesize wall material extends well into its postharvest life.

The increase in Calcofluor fluorescence observed in leathery tissue is more evidence for cellulose deposition. There are data showing that despite the presence of cellulase during softening, cell wall cellulose does not decrease as ripening proceeds (Ferguson, 1984; Hobson, 1968). Our observations of increased staining for $\beta 1,4$ glucans in cell walls may indicate cellulose synthesis. Therefore, some of the major structural changes related to softening, and later to $\mathrm{CI}$, are those related to loosening of cell walls, loss of wall cohesion, development of an intercellular matrix with new carbohydrates and pectins, and apparent cell wall synthesis. Cell wall degradation was observed only in decaying tissue due to presence of fungi.

\section{Literature Cited}

Archibald, R.D. and L.D. Melton. 1987. The anatomy of the fleshy pericarp of maturing Moorpark apricots, Prunus armeniaca. N.Z. J. Bet. 25:181-184.

Ben-Arie, R., N. Kislev, and C. Frenkel. 1979. Ultrastructural changes in the cell walls of ripening apple and pear fruit. Plant Physiol. 64:197-202.

Ben-Arie, R. and S. Lavee. 1971. Pectic changes occurring in Elberta peaches suffering from woolly breakdown. Photochemistry 10:531538.

Ben-Arie, R. and L. Sonego. 1980. Pectolytic enzyme activity involved in woolly breakdown of stored peaches. Photochemistry 19:2553-2555.

Buescher, R.W. and R.J. Furmanski. 1978. Role of pectinesterase and polygalacturonase in the formation of woolliness in peaches. J. Food Sci. 43:264-266.

Dawes, C.J. 1979. Biological techniques for transmission and scanning electron microscopy. Ladd Research Industries, Baltimore.

Dick, A.J. and J.M. Labavitch. 1989. Cell wall metabolism in ripening fruit: IV. Characterization of the pectic polysaccharides solubilized during softening of 'Bartlett' pear fruit. Plant Physiol. 89:13941400 .

Ferguson, I.B. 1984. Calcium in plant senescence and fruit ripening. Plant, Cell \& Environ. 7:477-489.

Furmanski, R. and R. Buescher. 1976. Woolliness in peach fruit, a serious problem affecting internal quality. Proc. Arkansas State Hort. Soc. 97:116-117.

Greve, L.C. and J.M. Labavitch. 1989. A GC-MS method using ${ }^{13}$ C6glucose label for evaluating synthesis of cell wall polysaccharides in ripening tomato pericarp disks. Plant Physiol. vol. 89. Abstr. 593.

Hobson, G.E. 1968. Cellulase activity during the maturation and ripening of tomato fruit. J Food Sci. 33:558-592.
Hughes, J. and M.E. McCully. 1975. The use of an optical brightener in the study of plant structure. Stain Technol. 50:319-329.

Jensen, W.A. 1962. Botanical histochemistry. W.H. Freeman \& Co., San Francisco.

Jermyn, M.A. and F.A. Isherwood. 1956. Changes in the cell wall of the pear during ripening. Biochem. J. 64:123-132.

Jewell, G.G. and C.A. Saxton. 1970. The ultrastructural demonstration of compounds containing 1,2-glycol groups in plant cell walls. Histochem. J. 2:17-22.

Khan, A.A. and J.F. Vincent. 1990. Anisotropy of apple parenchyrna. J. Sci. Food Agr. 52:455-466.

King, G.A., K.G. Henderson, and R.E. Lill. 1989. Ultrastructural changes in the nectarine cell wall accompanying ripening and storage in a chilling-resistant and chilling-sensitive cultivar. N. Z. J. Crop Hort. Sci. 17:337-344.

Labavitch, J.M. 1981. Cell wall turnover in plant development. Annu. Rev. Plant Physiol. 32:385-406.

Lill, R. E., E.M. O'Donaghue, and G.A. King. 1989. Postharvest physiology of peaches and nectarines. Hort. Rev. 11:413-452.

Mitcham, E. J., K.C. Gross, and T.J Ng. 1989. Tomato fruit cell wall synthesis during development and senescence: In vivo radiolabelling of wall fractions using $\left[{ }^{14} \mathrm{C}\right]$ sucrose. Plant Physiol. 89:477-481.

Mitchell, F.G. and A.A. Kader. 1989. Factors affecting deterioration rate, p. 165-178. In: J.H. LaRue and R.S. Johnson (eds.). Peaches, plums, and nectarines-Growing and handling for fresh market. Publ. 3331, Univ. of California, Div. of Agr. and Natural Resources, Oakland.

Mitchell, F. G., G. Mayer, E.C. Maxie, and W.W. Coates. 1974. Cold storage effects on fresh market peaches, nectarines and plums: I. Estimating freezing points, IL Using low temperatures to delay internal breakdown. Calif. Agr. 28(10):12-14.

Morris, L.L. 1982. Chilling injury of horticultural crops: An overview. HortScience 17:161-162.

O'Brien, T.P. and M.E. McCully. 1981. The study of plant structure: Principles and selected methods. Termarcarphi Pty. Melbourne, Australia.

Pearse, A.G.E. 1972. Histochemistry theoretical and applied. Churchill-Livingston, London.

Reeve, R.M. 1970. Relationship of histological structure to texture of fresh and processed fruits and vegetables. Review paper. J. Texture Studies 1:247-284.

Shewfelt, A.L. 1965. Changes and variations in the pectic constitution of ripening peaches as related to product firmness. J. Food. Sci. 30:573-576.

Ueda, K. and S. Yoshioka. 1976. Cell wall development of Micrasterias americana, especially in isotonic and hypertonic solutions. J. Cell Sci. 21:617.

Van Duijn, P. 1961. Acrolein-Schiff, a new staining method for protein. J. Histology Cytol. 9:234-241.

Weis, K. G., V.S. Polito, and J.M. Labavitch. 1988. Microfluorometry of pectic materials in the dehiscence zone of almond (Prunus dulcis [Mill] DA Webb) fruits. J. Histochem. Cytochem. 36:1037-1041. 